\title{
Anti-tumor effect of cimetidine via inhibiting angiogenesis factors in $N$-butyl- $N$-(4-hydroxybutyl) nitrosamine-induced mouse and rat bladder carcinogenesis
}

\author{
YOSHITOMO CHIHARA $^{1}$, KIYOHIDE FUJIMOTO ${ }^{1}$, MAKITO MIYAKE ${ }^{1}$, \\ YOSHIO HIASA ${ }^{2}$ and YOSHIHIKO HIRAO ${ }^{1}$ \\ ${ }^{1}$ Department of Urology, Nara Medical University, Kashihara; ${ }^{2}$ Pathology Division, \\ Prefectural Nara Hospital, Nara, Japan
}

Received January 12, 2009; Accepted April 6, 2009

DOI: 10.3892/or_00000401

\begin{abstract}
The aim of this study was to assess the anti-tumor effect and mechanisms of cimetidine in $N$-butyl- $N$-(4hydroxybutyl) nitrosamine (BBN)-induced bladder carcinogenesis model. Sixty-three male BALB/c mice and 67 male Wister rats were treated with $\mathrm{BBN}$ and cimetidine to examine the anti-tumor effect of cimetidine. Immunohistochemistry (IHC) of vascular endothelial growth factor (VEGF), plateletderived endothelial growth factor (PDECGF), and E-selectin were examined to compare their expression in the tumor tissues. In mice, the tumor growth was reduced by cimetidine $(p=0.011)$. The expression of PDECGF was reduced in the cimetidine-treated group $(\mathrm{p}=0.016)$. In rats, treatment of cimetidine reduced tumor growth $(\mathrm{p}=0.0001)$. Moreover, the expression of VEGF and PDECGF was reduced $(\mathrm{p}=0.02$ and $<0.001$, respectively). The expression of E-selectin did not correlate with the tumor growth in either mice or rats. In mice, long-term cimetidine treatment proved very effective for inhibiting the tumor growth, but in rats, BBN after treatment with cimetidine showed the least tumor growthinhibitory effect. In conclusion, cimetidine may have an inhibitory effect on tumor growth in bladder carcinogenesis via reducing the expression of angiogenesis factors including VEGF and PDECGF.
\end{abstract}

\section{Introduction}

Cimetidine, a histamine-2 (H2) receptor antagonist, reportedly improves the survival of patients with colorectal cancer, melanoma and renal cell carcinoma (1-3). It is interesting that the other $\mathrm{H} 2$ receptor antagonists, such as ranitidine and famotidine, do not demonstrate such effects $(4,5)$. Studies of

Correspondence to: Dr Yoshitomo Chihara, Department of Urology, Nara Medical University, 840 Shijo-cho, Kashihara-City, 631-0846, Nara, Japan

E-mail: yychihara@gmail.com

Key words: bladder cancer, cimetidine, angiogenesis, animal model the anti-tumor effects of cimetidine indicate multiple potential mechanisms of action, characterized by three overall features. One possible explanation is that cimetidine may show a direct inhibitory effect on tumor growth by blocking the cell growth-promoting activity of histamine-associated angiogenesis including the vascular endothelial growth factor (VEGF) (6,7). The second possibility is a cell-mediated immunomodulation by enhancing the host immune response to the tumor cells $(8,9)$. The third is that cimetidine exerts a tumor-suppressive effect via E-selectin-mediated cell adhesion (10). However, the exact mechanism by which cimetidine exerts an anti-tumor effect is still poorly understood.

Angiogenesis is essential for the growth of bladder cancer, and several studies revealed overexpression of VEGF and platelet-derived endothelial growth factor (PDECGF) in the tumor tissue using animal models and bladder cancer patients, and that overexpression correlated with poor prognosis (11-14). Furthermore, cimetidine showed tumor-suppressor effect via inhibiting this angiogenesis and cell adhesion in several studies using animal cancer models as described above. Herein, we investigated the effect of cimetidine on tumor growth and the expression of several factors which were considered as targets using animal models of bladder cancer induced by $N$-butyl$N$-(4-hydroxybutyl) nitrosamine (BBN).

\section{Materials and methods}

Animals and treatment. Sixty-three male BALB/c mice and 67 male Wister rats (SLC Japan, Shizuoka, Japan) at 5 weeks of age were used in this study. Cimetidine, courtesy of Dainippon Sumitomo Pharma Co., Ltd., Japan, was dissolved in autoclaved drinking water at a concentration of $1 \mathrm{mg} / \mathrm{ml}$. This corresponded to a dose of $100 \mathrm{mg} / \mathrm{kg} / \mathrm{day}$, which reportedly produced an effective cimetidine level in murine plasma $(15,16)$. Both BBN (Tokyo Kasai Kogyo, Tokyo, Japan) at a concentration of $0.05 \%$ and cimetidine were given in drinking tap water. After 1-week acclimation period; i.e., at the age of 6 weeks, the animals were divided into 4 groups as shown in Fig. 1; Group A: no treatment with BBN or cimetidine, Group B: BBN was administered for 9 weeks to rats and for 12 weeks to mice, Group C: after BBN treatment, cimetidine was given continuously until the animals were 


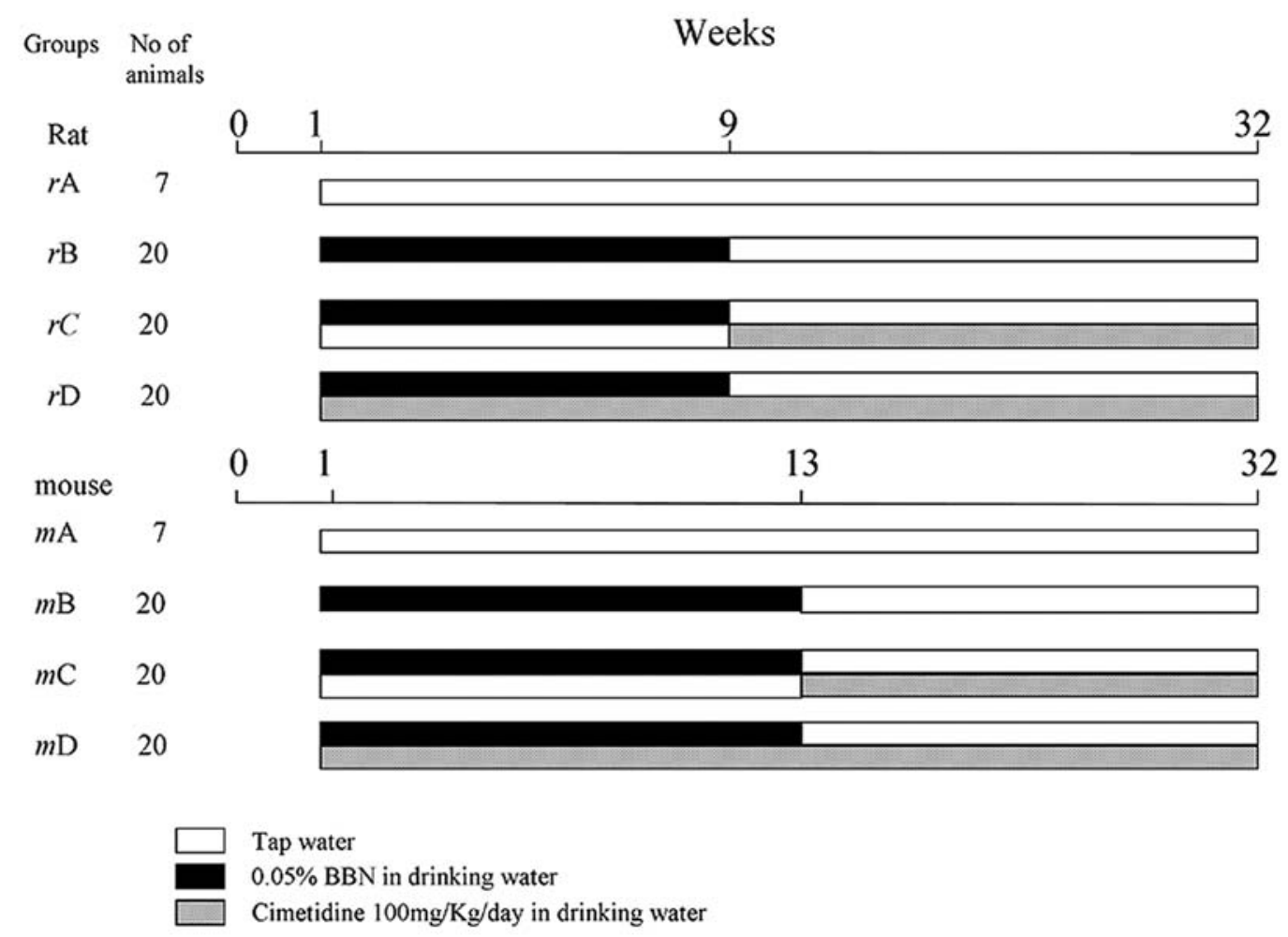

Figure 1. Schematic diagram showing the experimental design. The letters $r$ and $m$ correspond to rats and mice, respectively.

sacrificed, Group D: cimetidine was given from week 1. All surviving animals were sacrificed by ether anesthesia at the end of week 32. The bladders were then sectioned along the long axis of the maximum tumor, fixed in formalin, processed, and embedded in paraffin. The blocks were sectioned at $4-\mu \mathrm{m}$ thickness and stained with hematoxylin and eosin (H\&E) for microscopic examination. All animal experiments were carried our according to our university ethics guidelines.

Immunohistochemistry. Certain sections were processed for IHC of VEGF, E-selectin, and PDECGF as described previously (17). The primary antibodies were affinity-purified polyclonal rabbit anti-VEGF (clone Z-CVF3; Zymed Laboratories Inc., USA, diluted at 1:200), polyclonal rabbit antiE-selectin (clone H-300; Santa Cruz Biotechnology Inc., USA, diluted at 1:200), and mouse monoclonal anti-PDECGF (clone PGF.44C; Lab Vision Corp., USA, diluted at 1:200). The intensity of staining was scored as follows: for VEGF; negative: $<10 \%$ positive tumor cells, moderate: $10-50 \%$ positive cells, positive: $>50 \%$ positive cells (13), for E-selectin; negative: $<1 \%$ positive cells, moderate: $<75 \%$ positive cells, positive: $>75 \%$ positive cells (18), and for PDECGF; negative: no staining, moderate: weak staining, positive: strong staining. The tumors were considered positive for PDECGF when 25\% of the neoplastic cells demonstrated moderate staining as described previously (19). All results were scored by one of the authors (H.Y.) without prior knowledge of the respective treatment of the animals (Fig. 2).

Statistical analysis. Statistical analysis was carried out by likelihood Chi-square analysis or Fisher's exact test. Probability values of $\mathrm{p}<0.05$ were considered significant.

\section{Results}

Primary tumor growth and the effects of cimetidine. In mice, tumors developed in the all groups treated with BBN; i.e., Groups $m \mathrm{~B}, m \mathrm{C}$, and $m \mathrm{D}$ (Table I, top). The incidence of tumors was $65 \%(13 / 20)$ in Group $m \mathrm{~B}, 47.1 \%(8 / 17)$ in Group $m \mathrm{C}$, and $25 \%(5 / 20)$ in Group $m \mathrm{D}$. Furthermore, the incidence of tumor growth decreased according to the terms of cimetidine administration. The statistical difference between Groups $m \mathrm{~B}$ and $m \mathrm{D}$ was significant ( $\mathrm{p}=0.011)$. However, only 5 animals $(25 \%)$ developed tumors in Group $m \mathrm{D}$, but all tumors were of stage more advanced than pTa. Regarding the grade, no significant difference was found, and no dysplastic lesions were observed in either group.

In rats, all animals of Group $r \mathrm{~B}$ developed tumors. Nine animals (45\%) in Group $r \mathrm{C}$ and 11 cases (55\%) in Group $r \mathrm{D}$ developed tumor growth (Table I, bottom). The decrease of tumor growth in Group $r \mathrm{~B}$ was was significantly different from that in Group $r \mathrm{C}(\mathrm{p}=0.00013)$ and Group $r \mathrm{D}(\mathrm{p}=0.00085)$. Regarding the stage, the cimetidine-treated groups (Groups $r \mathrm{C}$ and $r \mathrm{D}$ ) showed significant inhibition of tumor invasion as compared with the non-cimetidine-treated group (Group $r \mathrm{~B}$ ) $(\mathrm{p}=0.0019)$. Furthermore, concerning the grade, Group $r \mathrm{C}$ developed lower grade tumors as compared with Group $r \mathrm{~B}$ $(\mathrm{p}=0.0035)$. However, there was no significant difference between Groups $r \mathrm{~B}$ and $r \mathrm{D}$.

The expression of VEGF, E-selectin, and PDECGF in tumors. The expression of VEGF, E-selectin, and PDECGF in the $\mathrm{BBN}$-induced tumor tissue were examined by IHC. In mice, VEGF and E-selectin were expressed in the normal urothelium and background neighboring healthy tissue, but the expression of PDECGF was not detected in the healthy tissue (Table II, 
(A)
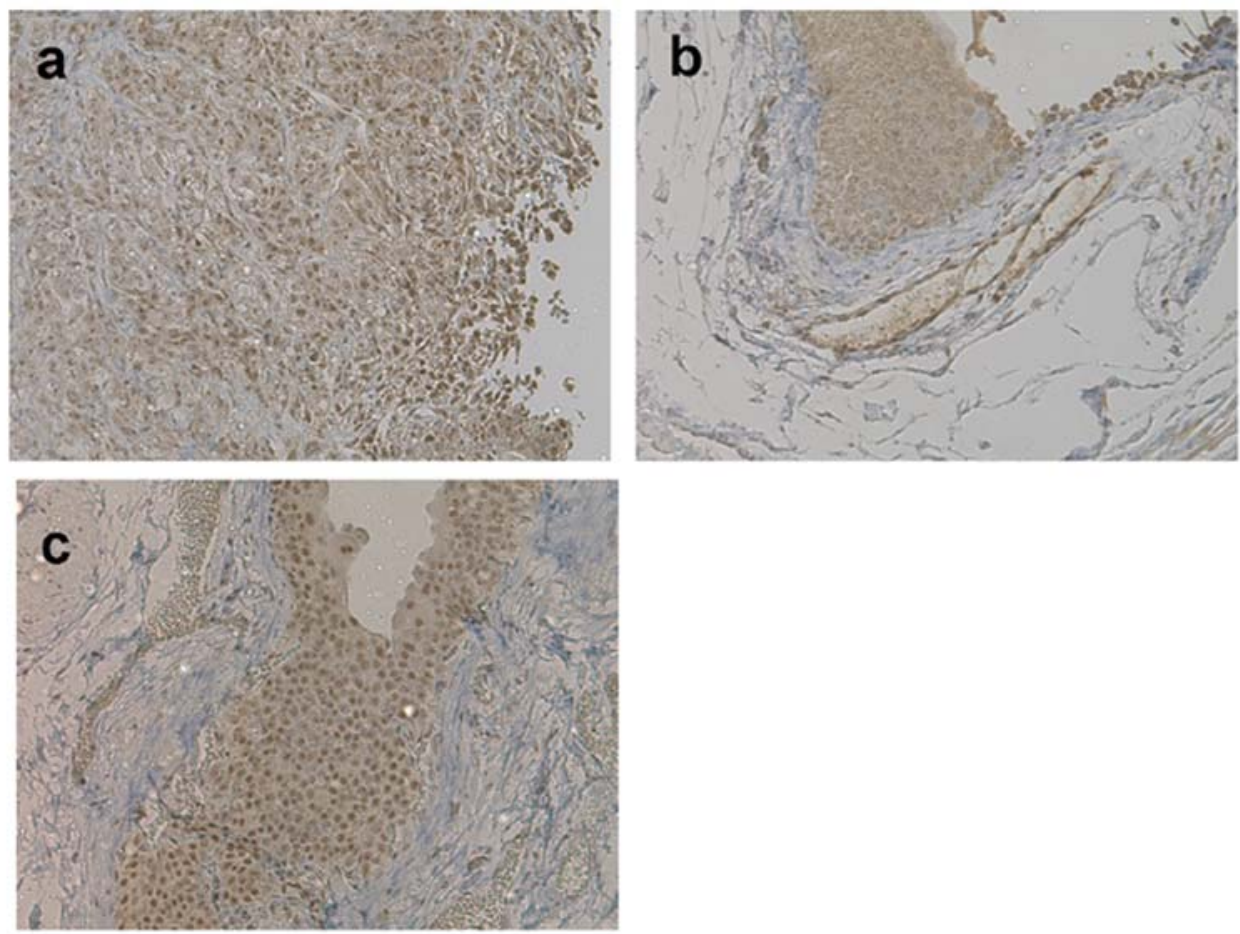

(B)
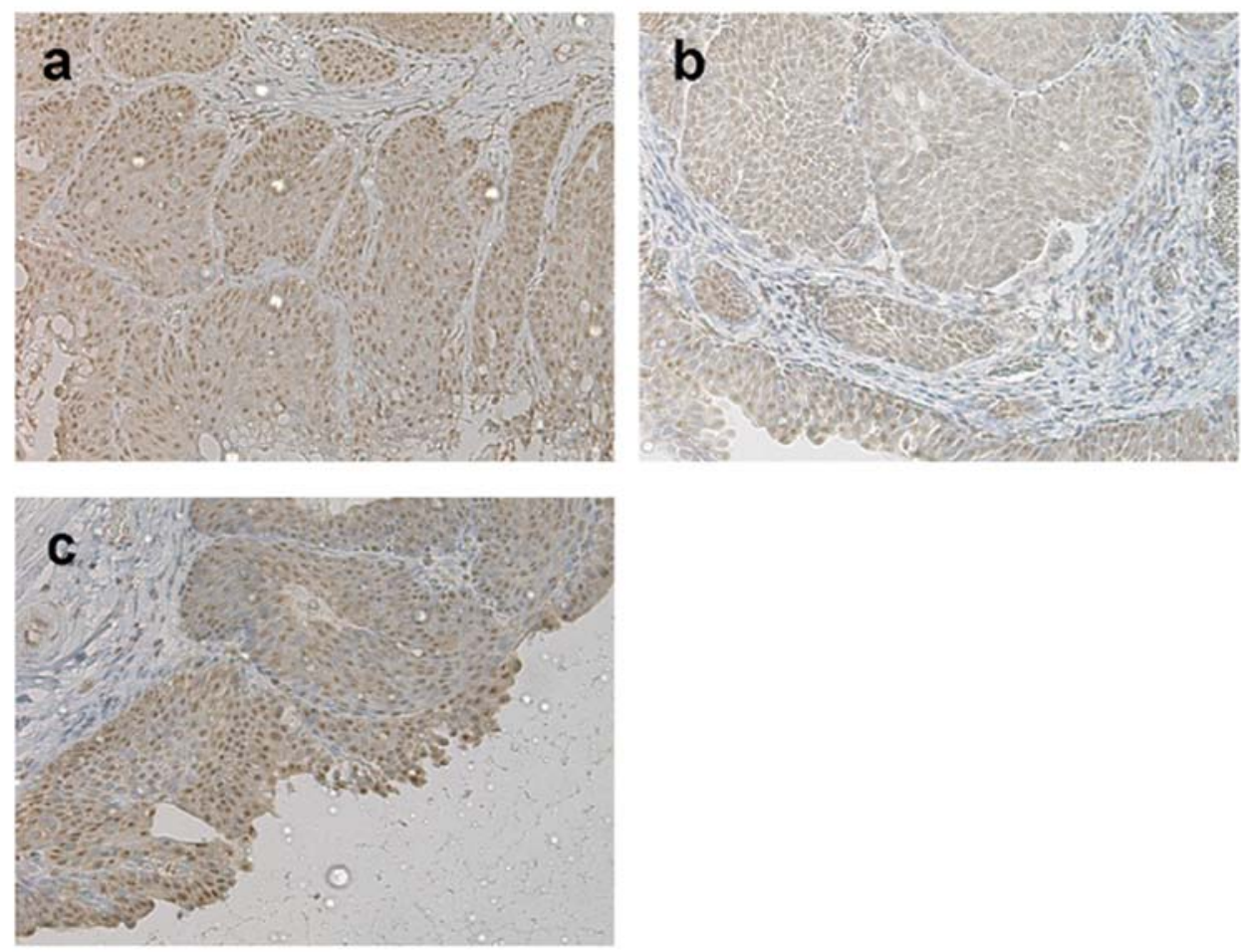

Figure 2. Immunohistochemical positive staining in tumors of VEGF (a), E-selectin (b), and PDECGF (c) in mice (A) and rats (B). The magnifications in all images are $\mathrm{x} 100$

top). Cimetidine treatment did not affect the expression of VEGF and E-selectin. On the other hand, long-term (Group $m D)$ cimetidine treatment significantly decreased the expression of PDECGF in the tumor tissue $(\mathrm{p}=0.016)$. In the rat $\mathrm{BBN}$ model, the healthy urothelium and adjacent healthy tissue did not express VEGF or PDECGF (Table II, bottom). The expression of VEGF decreased significantly by cimetidine treatment after BBN (i.e., Group $r \mathrm{C})(\mathrm{p}=0.021)$. The expression of PDECGF was detected in all tumor tissues of BBN alone-treated mice (Group $r \mathrm{~B}$ ). Moreover, the cimetidinetreated group showed significantly decreased expression of PDECGF in the tumors. These results were somewhat different from those in the mouse group, because the reduction of PDECGF expression was more remarkable in Group $r \mathrm{C}$ than 
Table I. Incidence of tumors cancer, stage and grade in the bladder of mice (top) and rats (bottom).

\begin{tabular}{|c|c|c|c|c|c|c|c|c|c|c|}
\hline & \multirow{2}{*}{ Treatment } & \multirow{2}{*}{ No. mice } & \multirow{2}{*}{$\begin{array}{l}\text { No. mice with } \\
\text { carcinoma }\end{array}$} & \multirow[b]{2}{*}{ Dysplasia } & \multicolumn{3}{|c|}{ Stage } & \multicolumn{3}{|c|}{ Grade } \\
\hline & & & & & $\mathrm{pTa}$ & pT1 & $\mathrm{pT} 1<$ & G1 & $\mathrm{G} 2$ & G3 \\
\hline Group $m \mathrm{~A}$ & None & 3 & $0(0 \%)$ & 0 & 0 & 0 & 0 & 0 & 0 & 0 \\
\hline Group $m \mathrm{~B}$ & $\mathrm{BBN}$ & 20 & $13(65 \%)$ & 0 & 6 & 1 & 6 & 0 & 6 & 7 \\
\hline Group $m \mathrm{C}$ & $\mathrm{BBN} \rightarrow \mathrm{CIM}$ & 17 & $8(47 \%)$ & 0 & 5 & 2 & 1 & 1 & 6 & 1 \\
\hline \multirow[t]{4}{*}{ Group $m \mathrm{D}$} & BBN+CIM & 20 & $5(25 \%)$ & 0 & 0 & 4 & 1 & 0 & 4 & 1 \\
\hline & & & $\begin{array}{l}m \mathrm{~B} \text { vs. } m \mathrm{C}: \mathrm{NS} \\
m \mathrm{~B} \text { vs. } m \mathrm{D}: \mathrm{a} \\
m \mathrm{C} \text { vs. } m \mathrm{D}: \mathrm{NS}\end{array}$ & & \multicolumn{3}{|c|}{$\begin{array}{l}m \mathrm{~B} \text { vs. } m \mathrm{C}: \mathrm{NS} \\
m \mathrm{~B} \text { vs. } m \mathrm{D}: \mathrm{b} \\
m \mathrm{C} \text { vs. } m \mathrm{D}: \mathrm{NS}\end{array}$} & \multicolumn{3}{|c|}{$\begin{array}{l}m \mathrm{~B} \text { vs. } m \mathrm{C}: \mathrm{NS} \\
m \mathrm{~B} \text { vs. } m \mathrm{D}: \mathrm{NS} \\
m \mathrm{C} \text { vs. } m \mathrm{D}: \mathrm{NS}\end{array}$} \\
\hline & \multirow{2}{*}{ Treatment } & \multirow{2}{*}{ No. rats } & \multirow{2}{*}{$\begin{array}{l}\text { No. rats with } \\
\text { carcinoma }\end{array}$} & \multirow[b]{2}{*}{ Dysplasia } & \multicolumn{3}{|c|}{ Stage } & \multicolumn{3}{|c|}{ Grade } \\
\hline & & & & & $\mathrm{pTa}$ & pT1 & $\overline{\mathrm{pT} 1<}$ & $\mathrm{G} 1$ & $\mathrm{G} 2$ & G3 \\
\hline Group $r \mathrm{~A}$ & None & 6 & $0(0 \%)$ & 0 & 0 & 0 & 0 & 0 & 0 & 0 \\
\hline Group $r \mathrm{~B}$ & $\mathrm{BBN}$ & 19 & $19(100 \%)$ & 0 & 5 & 14 & 0 & 10 & 9 & 0 \\
\hline Group $r \mathrm{C}$ & $\mathrm{BBN} \rightarrow \mathrm{CIM}$ & 20 & $9(45 \%)$ & 8 & 8 & 1 & 0 & 1 & 8 & 0 \\
\hline \multirow[t]{4}{*}{ Group rD } & $\mathrm{BBN}+\mathrm{CIM}$ & 20 & $11(55 \%)$ & 7 & 2 & 9 & 0 & 5 & 6 & 0 \\
\hline & & & $r \mathrm{~B}$ vs. $r \mathrm{C}: \mathrm{c}$ & & \multicolumn{3}{|c|}{$r \mathrm{~B}$ vs. $r \mathrm{C}: \mathrm{b}$} & \multicolumn{3}{|c|}{$r \mathrm{~B}$ vs. $r \mathrm{C}: \mathrm{a}$} \\
\hline & & & $r \mathrm{~B}$ vs. $r \mathrm{D}: \mathrm{c}$ & & \multicolumn{3}{|c|}{$r \mathrm{~B}$ vs. $r \mathrm{D}: \mathrm{NS}$} & \multicolumn{3}{|c|}{$r \mathrm{~B}$ vs. $r \mathrm{D}: \mathrm{NS}$} \\
\hline & & & $r \mathrm{C}$ vs. $r \mathrm{D}: \mathrm{NS}$ & & \multicolumn{3}{|c|}{$r \mathrm{C}$ vs. $r \mathrm{D}: \mathrm{b}$} & \multicolumn{3}{|c|}{$r \mathrm{C}$ vs. $r \mathrm{D}: \mathrm{NS}$} \\
\hline
\end{tabular}

${ }^{\mathrm{a}} \mathrm{p}<0.05,{ }^{\mathrm{b}} \mathrm{p}<0.01,{ }^{\mathrm{c}} \mathrm{p}<0.001$. NS, no significance; CIM, cimetidine.

in the long-term cimetidine-treated group (i.e., Group $r \mathrm{D}$ ) $(\mathrm{p}=0.0047)$. Furthermore, the reduction of PDECGF expression was significantly different between Groups $r \mathrm{C}$ and $r \mathrm{D}$ $(\mathrm{p}=0.017)$.

\section{Discussion}

Cimetidine proved to be a potent growth inhibitor of tumor volume and weight in mice inoculated with colon adenocarcinoma cells, and these studies showed that cimetidine inhibited the angiogenic factors in the tumor tissue including VEGF $(6,7)$. Another study showed that cimetidine might block cancer metastasis through blocking adhesion of tumor cells to the endothelium via interaction between E-selectin and sialyl-Lewis antigens (20). Several studies indicated that the expression levels of VEGF and PDECGF influenced the progression of transitional cell carcinoma (TCC) in the animal models (11-14), as well as the prognosis of the TCC patients (11). In this study, we examined the effect of cimetidine on tumor growth using BBN-induced carcinogenesis in the mouse and rat models.

In both mice and rats, the cimetidine treatment significantly reduced the development of tumors. These results were somewhat different in each group. In mice, the development of TCC was reduced in the group treated with long-term cimetidine $(\mathrm{p}=0.011)$. On the other hand, in rats, the group treated with cimetidine after BBN showed less frequency of tumor growth $(\mathrm{p}<0.00013)$.
PDECGF is the enzyme involved in the salvage pathway of pyrimidine nucleotide syntheses (21), and many studies revealed overexpression of PDECGF, among many angiogenic factors, in the bladder cancer, suggesting that stage and grade progression correlated with PDECGF expression $(11,22,23)$. In our IHC, the expression of PDECGF was not detected in the healthy urothelium and adjacent healthy tissue. The expression of PDECGF in the tumor tissue was reduced in both mice and rats, and these results correlated with the frequency of tumor growth. VEGF is a well known potential mediator of tumor-associated neovascularization in vivo since it is up-regulated in various human cancers including bladder cancer. Furthermore, several studies demonstrated that VEGF and PDECGF were frequently co-expressed in the tumor tissue (24). In our study, the expression of VEGF was different between mice and rats. In mice, the healthy urothelium showed expression of VEGF, and this expression did not differ by cimetidine treatment. However, in rats, VEGF expression was not detected in the healthy tissue, and the cimetidine-treated groups showed significant reduction of the VEGF expression ( $\mathrm{p}=0.021)$. In addition, we did not find any correlation between PDECGF and VEGF.

We referred to another mechanism of cimetidine concerned with cell adhesion via E-selectin. Previously, Kobayashi et al reported that cimetidine down-regulated the expression of Eselectin, a ligand for sialyl-Lewis antigens, in colon cancer cells, and that it suppressed cell adhesion to the endothelium resulting in suppression of metastasis (10). In our study, the 
Table II. The expression of VEGF, E-selectin and PDECGF in tumors of mice (top) and rats (bottom).

\begin{tabular}{|c|c|c|c|c|c|c|c|c|}
\hline & \multirow{2}{*}{ Treatment } & \multirow{2}{*}{$\begin{array}{l}\text { No. mice with } \\
\text { carcinoma }\end{array}$} & \multicolumn{2}{|c|}{ VEGF } & \multicolumn{2}{|c|}{ E-selectin } & \multicolumn{2}{|c|}{ PDECGF } \\
\hline & & & Neg./Mod. & Pos. & Neg./Mod. & Pos. & Neg./Mod. & Pos. \\
\hline Group $m \mathrm{~A}$ & None & - & 0 & 3 & 0 & 3 & 3 & 0 \\
\hline Group $m \mathrm{~B}$ & $\mathrm{BBN}$ & 13 & 3 & 10 & 3 & 10 & 1 & 12 \\
\hline Group $m \mathrm{C}$ & $\mathrm{BBN} \rightarrow \mathrm{CIM}$ & 8 & 2 & 6 & 3 & 5 & 2 & 6 \\
\hline \multirow[t]{6}{*}{ Group $m \mathrm{D}$} & $\mathrm{BBN}+\mathrm{CIM}$ & 5 & 3 & 2 & 1 & 4 & 3 & 2 \\
\hline & & & \multirow{3}{*}{\multicolumn{2}{|c|}{$\begin{array}{l}m \mathrm{~B} \text { vs. } m \mathrm{C}: \mathrm{NS} \\
m \mathrm{~B} \text { vs. } m \mathrm{D}: \mathrm{NS} \\
m \mathrm{C} \text { vs. } m \mathrm{D}: \mathrm{NS}\end{array}$}} & \multirow{3}{*}{\multicolumn{2}{|c|}{$\begin{array}{l}m \mathrm{~B} \text { vs. } m \mathrm{C}: \mathrm{NS} \\
m \mathrm{~B} \text { vs. } m \mathrm{D}: \mathrm{NS} \\
m \mathrm{C} \text { vs. } m \mathrm{D}: \mathrm{NS}\end{array}$}} & \multirow{3}{*}{\multicolumn{2}{|c|}{$\begin{array}{l}m \mathrm{~B} \text { vs. } m \mathrm{C}: \mathrm{NS} \\
m \mathrm{~B} \text { vs. } m \mathrm{D}: \mathrm{a} \\
m \mathrm{C} \text { vs. } m \mathrm{D}: \mathrm{NS}\end{array}$}} \\
\hline & & & & & & & & \\
\hline & & & & & & & & \\
\hline & \multirow{2}{*}{ Treatment } & \multirow{2}{*}{$\begin{array}{l}\text { No. rats with } \\
\text { carcinoma }\end{array}$} & \multicolumn{2}{|c|}{ VEGF } & \multicolumn{2}{|c|}{ E-selectin } & \multicolumn{2}{|c|}{ PDECGF } \\
\hline & & & Neg./Mod. & Pos. & Neg./Mod. & Pos. & Neg./Mod. & Pos. \\
\hline Group $r \mathrm{~A}$ & None & - & 6 & 0 & 3 & 3 & 6 & 0 \\
\hline Group $r \mathrm{~B}$ & $\mathrm{BBN}$ & 19 & 11 & 8 & 4 & 15 & 0 & 19 \\
\hline Group $r \mathrm{C}$ & $\mathrm{BBN} \rightarrow \mathrm{CIM}$ & 9 & 9 & 0 & 1 & 8 & 8 & 1 \\
\hline \multirow[t]{4}{*}{ Group $r D$} & $\mathrm{BBN}+\mathrm{CIM}$ & 11 & 10 & 1 & 8 & 3 & 4 & 7 \\
\hline & & & \multicolumn{2}{|c|}{$r \mathrm{~B}$ vs. $r \mathrm{C}: \mathrm{a}$} & \multicolumn{2}{|c|}{$r \mathrm{~B}$ vs. $r \mathrm{C}: \mathrm{NS}$} & \multicolumn{2}{|c|}{$r \mathrm{~B}$ vs. $r \mathrm{C}: \mathrm{b}$} \\
\hline & & & \multicolumn{2}{|c|}{$r \mathrm{~B}$ vs. $r \mathrm{D}: \mathrm{NS}$} & \multicolumn{2}{|c|}{$r \mathrm{~B}$ vs. $r \mathrm{D}: \mathrm{NS}$} & \multicolumn{2}{|c|}{$r \mathrm{~B}$ vs. $r \mathrm{D}: \mathrm{a}$} \\
\hline & & & \multicolumn{2}{|c|}{$r \mathrm{C}$ vs. $r \mathrm{D}: \mathrm{NS}$} & \multicolumn{2}{|c|}{$r \mathrm{C}$ vs. $r \mathrm{D}: \mathrm{NS}$} & \multicolumn{2}{|c|}{$r \mathrm{C}$ vs. $r \mathrm{D}: \mathrm{a}$} \\
\hline
\end{tabular}

${ }^{\mathrm{a}} \mathrm{p}<0.05,{ }^{\mathrm{b}} \mathrm{p}<0.001$. NS, no significance; CIM, cimetidine.

expression of E-selectin in the tissue was detected in $100 \%$ $(3 / 3)$ of mice and $50 \%(3 / 6)$ of rats. Nonetheless, cimetidine treatment did not affect the expression of E-selectin in the tumor tissue in either mice or rats. Our results may be attributed to the difference of cancer cells and the expression of sialyl-Lewis antigens. However, our results probably indicate that the anti-metastatic effect of cimetidine did not correlate with carcinogenesis.

In conclusion, our findings in the BBN-induced bladder cancer models partially supported that the anti-tumor effect of cimetidine is mediated via suppression of angiogenic factors including VEGF and PDECGF. Cimetidine is widely used to manage gastro-esophageal reflex diseases and gastric and duodenal ulcers without serious adverse effects, and may be a useful adjuvant for bladder cancer. Further molecular studies are necessary to determine the mechanism of cimetidineinduced anti-tumor effect.

\section{Acknowledgements}

The authors sincerely thank Dainippon Sumitomo Pharma Co., Ltd., Japan, for preparing cimetidine, and Tomoko Sakon and Sayuri Onisi (Department of Urology, Nara Medical University) for their considerable contribution in the experimental techniques.

\section{References}

1. Matsumoto S: Cimetidine and survival with colorectal cancer. Lancet 346: 115, 1995.
2. Morris DL and Adams WJ: Cimetidine and colorectal cancerold drug, new use? Nat Med 1: 1243-1244, 1995.

3. Sagaster P, Micksche M, Flamm J and Ludwig H: Randomised study using IFN-alpha versus IFN-alpha plus coumarin and cimetidine for treatment of advanced renal cell cancer. Ann Oncol 6: 999-1003, 1995.

4. Lawson JA, Adams WJ and Morris DL: Ranitidine and cimetidine differ in their in vitro and in vivo effects on human colonic cancer growth. Br J Cancer 73: 872-876, 1996.

5. Hahm KB, Kim WH, Lee SI, Kang JK and Park IS: Comparison of immunomodulative effects of the histamine-2 receptor antagonists cimetidine, ranitidine, and famotidine on peripheral blood mononuclear cells in gastric cancer patients. Scand J Gastroenterol 30: 265-271, 1995.

6. Natori T, Sata M, Nagai R and Makuuchi M: Cimetidine inhibits angiogenesis and suppresses tumor growth. Biomed Pharmacother 59: 56-60, 2005.

7. Tomita K, Izumi K and Okabe S: Roxatidine- and cimetidineinduced angiogenesis inhibition suppresses growth of colon cancer implants in syngeneic mice. J Pharmacol Sci 93: 321-330, 2003.

8. Kubota T, Fujiwara H, Ueda Y, et al: Cimetidine modulates the antigen presenting capacity of dendritic cells from colorectal cancer patients. Br J Cancer 86: 1257-1261, 2002.

9. Takahashi K, Tanaka S, Furuta K and Ichikawa A: Histamine $H(2)$ receptor-mediated modulation of local cytokine expression in a mouse experimental tumor model. Biochem Biophys Res Commun 297: 1205-1210, 2002.

10. Kobayashi K, Matsumoto S, Morishima T, Kawabe T and Okamoto T: Cimetidine inhibits cancer cell adhesion to endothelial cells and prevents metastasis by blocking E-selectin expression. Cancer Res 60: 3978-3984, 2000.

11. Fujimoto K, Matsumura Y, Tani Y, Ozono S, Hirao Y and Okajima E: Tissue levels of pyrimidine nucleoside phosphorylase activity in human and rodent bladder cancer and normal bladder tissue. Int J Urol 14: 754-759, 2007.

12. Brown NS, Jones A, Fujiyama C, Harris AL and Bicknell R: Thymidine phosphorylase induces carcinoma cell oxidative stress and promotes secretion of angiogenic factors. Cancer Res 60: 6298-6232, 2000. 
13. Nadaoka J, Horikawa Y, Saito M, et al: Prognostic significance of HIF-1 alpha polymorphisms in transitional cell carcinoma of the bladder. Int J Cancer 122: 1297-1302, 2008.

14. Wakui S, Furusato M, Sasaki S, Muto T, Takahashi H, Masaoka T and Ushigome S: Expression of vascular endothelial growth factor in N-butyl-N-(4-hydroxybutyl)nitrosamine-induced rat bladder carcinogenesis. Vet Pathol 36: 111-116, 1999.

15. Adams WJ, Lawson JA, Nicholson SE, Cook TA and Morris DL: The growth of carcinogen-induced colon cancer in rats is inhibited by cimetidine. Eur J Surg Oncol 19: 332-335,1993.

16. Gifford RRM, Ferfuson RM and Voss BV: Cimetidine reduction of tumor formation in mice. Lancet 1: 638-640, 1981

17. Chihara Y, Sugano K, Kobayashi Y, et al: Loss of bloodgroup A antigen expression in bladder cancer caused by allelic loss and/or methylation of the ABO gene. Lab Invest 85: 895-907, 2005.

18. Dimitroff CJ, Descheny L, Trujillo N, et al: Identification of leukocyte E-selectin ligands, P-selectin glycoprotein ligand-1 and E-selectin ligand-1, on human metastatic prostate tumor cells. Cancer Res 65: 5750-5760, 2005.

19. Arima J, Imazono Y, Takebayashi Y, et al: Expression of thymidine phosphorylase as an indicator of poor prognosis for patients with transitional cell carcinoma of the bladder. Cancer 88: 1131-1138, 2000.
20. Matsumoto S, Imaeda Y, Umemoto S, Kobayashi K, Suzuki H and Okamoto T: Cimetidine increases survival of colorectal cancer patients with high levels of sialyl Lewis-X and sialyl Lewis-A epitope expression on tumour cells. Br J Cancer 86: $161-167,2002$

21. Fujimoto K, Hosotani R, Wada M, et al: Expression of two angiogenic factors, vascular endothelial growth factor and platelet-derived endothelial cell growth factor in human pancreatic cancer, and its relationship to angiogenesis. Eur J Cancer 34: 1439-1447, 1998.

22. Nonomura N, Nakai Y, Nakayama M, et al: The expression of thymidine phosphorylase is a prognostic predictor for the intravesical recurrence of superficial bladder cancer. Int J Clin Oncol 11: 297-302, 2006.

23. Aoki S, Yamada Y, Nakamura K, Taki T, Tobiume M and Honda N: Thymidine phosphorylase expression as a prognostic marker for predicting recurrence in primary superficial bladder cancer. Oncol Rep 16: 279-284, 2006.

24. Toi M, Inada K, Hoshina S, Suzuki H, Kondo S and Tominaga T: Vascular endothelial growth factor and platelet-derived endothelial cell growth factor are frequently coexpressed in highly vascularized human breast cancer. Clin Cancer Res 9: 961-964, 1995. 